\section{Factors associated with undernourishment among people 20 years old or over with HIV/AIDS attending public health services in the São Paulo municipality, Brazil}

\author{
Fatores associados à desnutrição em pessoas \\ com 20 anos e mais, com HIV/AIDS, em serviços \\ públicos de saúde no Município de São Paulo, \\ Brasil
}

Factores asociados a la desnutrición en personas con 20 años o más, portadores de VIH/SIDA, en los servicios públicos de salud de la ciudad de São Paulo, Brasil

\begin{abstract}
The study evaluated the nutritional status of 629 people living with HIVIAIDS attended at 12 specialized services of São Paulo's Municipal Health Department, Brazil. Data were obtained from medical records and through interviews during nutritional consultation. We used the classification criteria established by World Health Organization to assess malnourished individuals, $a$ $B M I<18.5 \mathrm{~kg} / \mathrm{m}^{2}$. The prevalence of malnutrition in people with AIDS is 3.12 times that observed among people with HIV, and among people with co-infection it is 3.41 times that obtained among people without co-infection. This indicates how these conditions can harm the maintenance of the nutritional status, and shows that they demand a comprehensive understanding of the mechanisms involved in this phenomenon, as well as the development of strategies to improve the health care of individuals at nutritional risk.
\end{abstract}

Malnutrition; Nutritional Status; Anthropometry; Acquired Immunodeficiency Syndrome; HIV
Katia Cristina Bassichetto 1 Denise Pimentel Bergamaschi 2 Vania Regina Salles Garcia ${ }^{3}$ Maria Amélia de Sousa Mascena Veras ${ }^{4}$

\section{Resumo}

O estudo avaliou a prevalência de desnutrição de 629 pessoas com HIVIAIDS, em 12 serviços especializados da Rede Municipal de Saúde de São Paulo, Brasil. Informações foram obtidas de prontuários e em entrevistas durante consulta de nutrição. Utilizou-se, para definição de desnutrição, o critério da Organização Mundial da Saúde (IMC $<18,5 \mathrm{~kg} / \mathrm{m}^{2}$ ). Observou-se que a prevalência de desnutrição em pessoas com AIDS é 3,12 vezes aquela verificada entre pessoas com HIV, e, entre pessoas com coinfecção, 3,41 vezes a obtida entre pessoas sem coinfecção. Isso indica que tais condições podem ser deletérias para a manutenção do estado nutricional, sendo recomendados uma compreensão mais aprofundada dos mecanismos envolvidos nesse fenômeno $e$ o desenvolvimento de estratégias para o cuidado integral de saúde dos indivíduos em risco nutricional.

Desnutrição; Estado Nutricional; Antropometria; Sindrome de Imunodeficiência Adquirida; HIV 


\section{Introduction}

Maintaining the nutritional status depends on a number of factors, such as proper intake of food, efficient absorption of nutrients, and proper metabolism. Changes in any of these over an extended period of time may lead to undernourishment 1 .

In people infected with the human immunodeficiency virus (HIV) or who present diseases caused by this infection - acquired immunodeficiency syndrome (AIDS), changes in these factors may occur concurrently, leading to nutritional deficiencies and impacting medical condition, and morbi-mortality. 1,2,3,4. These deficiencies interfere with nutritional needs; therefore monitoring the nutritional status and timely interventions may contribute to stabilizing the clinical condition of these individuals.

To face this reality, one of the public policies adopted in Brazil - the free distribution of highly-active antiretroviral therapy (HAART) for individuals with HIV/AIDS - has contributed to a decrease in mortality. However, this also affected the nutritional and metabolic profile of individuals presenting this condition, including, as mentioned in the literature, an increase in prevalence of metabolic syndrome, and changes in body composition, with fat loss in peripheral areas of the body and fat gain in the central areas. These changes are associated with the progression of the disease, type and length of treatment, compliance to treatment, and adverse effects of HAART, among others $3,4,5,6,7,8,9$.

Despite the nutritional transition observed, undernourishment is still present, and may affect quality of life and morbi-mortality of HIV/AIDS individuals $2,3,4,5$. The progressive weight loss, and a marked reduction of energy intake from combined medical complications, such as recurrent opportunistic infections leading to loss of appetite, anemia, increase of energy expenditure, decreased nutrient utilization, and drug-related secondary digestive abnormalities may lead to undernourishment 2,10. Thus, early identification and characterization of the different risk factors that may cause such conditions are important to lead the development of specific strategies and to prevent more serious medical consequences that raise morbidity and mortality risks which occur from a weight loss around 5\% 4,10,11,12.

In addition, recent evidences have shown that individuals with HIV/AIDS are more susceptible to secondary infections and to the early development of advanced signs of frailty in association with chronic inflammation and adverse effects of HAART, making the long-term medical management more difficult $13,14,15,16$. The complexity of
HIV infection and its consequences reinforce the need of health-related actions to maintain the nutritional status of this group of patients. As the subjects of most Brazilian studies on this matter are patients of one single clinic, 13,14,17,18,19,20,21 and few include a higher number of clinics connected to a health care network $15,16,22,23$, the investigations on the nutritional status of HIV/ AIDS individuals, particularly those focusing on undernourishment, in a sample of patients attended in a public healthcare network with facilities broadly distributed over a geographic area, such as the one of the city of São Paulo, Brazil, may contribute for the understanding of this phenomenon.

The purpose of this study is to assess the magnitude of undernourishment, and to investigate factors related to its occurrence in individuals aged 20 years or older individuals with HIV/ AIDS, in Specialized Care Clinics (SCC) of the City of São Paulo Public Health Care Network in 2008 and 2009.

\section{Materials and methods}

\section{Type of study and sample selection}

This was a cross-sectional study carried out between January 2008 and September 2009, with HIV/AIDS individuals aged 20 years and older in 12 out of 15 SCC of the São Paulo's Municipal Health Department (SMS-SP), which form the city's STD/AIDS Specialized Health Care Network. These clinics provide ongoing specialized medical services by multiprofessional teams, which include the assessment of the nutritional status in compliance with the protocol established by the Brazilian Ministry of Health 24 .

To calculate the size of the sample, it was considered a proportion of undernourishment estimated in 5\%, 95\%confidence interval, and 1.5\% accuracy. After adjustment for a finite population (19,097 individuals in follow-up), and $20 \%$ loss, the sample size was 956 . By applying the $74.5 \%$ proportion of people in follow-up aged 20 years and over, the final sample size was 696 .

The sample size necessary for each clinic was established proportionally to the demand for services seen at the time, from a report generated by a Services Surveillance System used by the STD/AIDS Specialized Health Network, and the service-provision capacity of each clinic. Being a stratified sample with subjects selected proportionally according to the size of the clinics, and not from the conglomerate, calculating the design effect was not considered necessary. 
Inclusion criteria included: having a positive serum HIV test or the mandatory AIDS notification form in the patient's chart; being followedup by one of the clinics, regardless of being or not attended at the outpatient nutrition clinic; signing the Informed Consent Form (ICF). Those who had hyper- or hypothyroidism, neurologic abnormalities, physical impairment making difficult anthropometric measurements, pregnancy, walking inability, and use of silicon prosthetics were excluded from the sample.

\section{Medical, anthropometirc and care data}

Data was collected from interviews during the nutrition consultation, when the patients answered a questionnaire designed for the investigation, with questions about the medical condition and care received. At this time, anthropometric measures were also taken. Information about the use of HAART at the time of the interview and the dates of the first positive serum HIV, and AIDS compulsory notification were obtained from the charts.

The "time known of being infected" and "time of follow up" were calculated "from the time elapsed between the date of the interview and the date of the first positive serum HIV", and "from the time elapsed between the date of the interview and the date of the first medical consultation in the clinic", respectively. In the analysis, time of follow-up was classified in two categories: below or above the median value $(<3.3$ and $\geq 3.3$ years).

The assessment of the nutritional status was made using the weight $(\mathrm{kg})$, height $(\mathrm{cm})$, and body mass index (BMI), which is calculated by dividing the weight in kilos $(\mathrm{kg})$ by the square of the height in meters (m). To ensure the quality of the data, the measures were taken by trained nutritionists, using the procedures recommended by Lohman et al. 25 and the World Health Organization (WHO) 26, with the weight obtained from a digital scale (Plenna, São Paulo, Brazil) with weight capacity of $150 \mathrm{~kg}$, with the patient in bare feet and wearing light clothes; height was measured by a fixed tape measure, and a set square to position the head on the Frankfurt plan. Anthropometric measurements were collected twice, and the mean of the values observed was used.

The classification of the nutritional status was according to the WHO-adapted criteria 26: $\mathrm{BMI}<18.5 \mathrm{~kg} / \mathrm{m}^{2}$ (undernourished), $18.5 \leq \mathrm{IMC}$ $<25.0 \mathrm{~kg} / \mathrm{m}^{2}$ (eutrophic), and BMI $\geq 25.0 \mathrm{~kg} /$ $\mathrm{m}^{2}$ (overweight). Malnutrition was used as the outcome variable, with two BMI categories (< $18.5 \mathrm{~kg} / \mathrm{m}^{2}$ : undernourished, and $\geq 18.5 \mathrm{~kg} / \mathrm{m}^{2}$ : non-undernourished).

\section{Statistical analysis}

The descriptive statistics mean, median, quartiles and frequencies were used as summary and position measures.

To describe the population of the study, the co-variables time known of being infected (years), and time of follow-up (years) were considered, both being summarized in median and quartiles. The distribution of the population according to sex; age group (20-39 years, and 4074 years); diagnosis (HIV or AIDS); HAART use among AIDS patients (yes, no); nutritional consultation prior to the investigation (yes, no); nutritional status (undernourished, eutrophic, and overweight), and co-infection (yes, no) (Table 1) were also presented. The considered co-infections were tuberculosis, $\mathrm{B}$ hepatitis, $\mathrm{C}$ hepatitis or any combination of these. All information was collected at the interview, during the nutritional assessment.

As the study included only 22 individuals of 60 years and older, it was decided to expand the age group to 40 years and over. Recent literature that uses these age groups investigate the impact of HIV/AIDS in "early aging" 27,28,29,30.

As measures of association, the decision was to consider point prevalence ratios (PR), and the $95 \%$ confidence interval $(95 \% \mathrm{CI})$, by means of a generalized linear regression model, of binomial family and logarithmic ligand binding 31 . Multiple modeling was started with the co-variables which, in the simple log-binomial model, had a $\mathrm{p}$ value lower than or equal to 0.2 , and with three control variables (sex, age, and time of followup). As almost all AIDS patients (94.3\%) used HAART, it was decided to use the variable "diagnosis", and not "HAART use" in the analysis.

Statistics of the tests that presented $\mathrm{p}$ values lower than or equal to 0.05 were considered statistically significant. Analysis was performed with the use of software Stata, version 11 (Stata Corp., College Station, United States).

\section{Ethical aspects}

This study was approved by the Ethics Research Committee, São Paulo's Municipal Health Department (SMS-SP registration number 252/2004), and the Informed Consent Form was signed, with reliability, and anonymity of the participants being assured. 
Table 1

Distribution of HIV/AIDS individuals cared at the City Health Care Network STD/AIDS Specialized Care Clinics according to demographic and clinical features. City of São Paulo, Brazil, 2008-2009.

\begin{tabular}{|c|c|c|}
\hline Characteristics & $\mathrm{n}$ & $\%$ \\
\hline \multicolumn{3}{|l|}{ Sex } \\
\hline Men & 311 & 49.4 \\
\hline Women & 318 & 50.6 \\
\hline \multicolumn{3}{|l|}{ Age group (years) } \\
\hline 20-39 & 338 & 53.7 \\
\hline $40-74$ & 291 & 46.3 \\
\hline \multicolumn{3}{|l|}{ Diagnosis } \\
\hline HIV & 209 & 33.2 \\
\hline AIDS & 420 & 66.8 \\
\hline \multicolumn{3}{|l|}{ Co-infection } \\
\hline No & 458 & 72.8 \\
\hline Yes & 171 & 27.2 \\
\hline \multicolumn{3}{|l|}{ HAART use * } \\
\hline Yes & 396 & 94.3 \\
\hline No & 24 & 5.7 \\
\hline \multicolumn{3}{|c|}{ Nutritional consultation prior to the } \\
\hline \multicolumn{3}{|l|}{ investigation } \\
\hline Yes & 381 & 60.6 \\
\hline No & 248 & 39.4 \\
\hline \multicolumn{3}{|l|}{ Nutritional status } \\
\hline Undernourished & 46 & 7.3 \\
\hline Eutrophic & 340 & 54.1 \\
\hline Overweight & 243 & 38.6 \\
\hline
\end{tabular}

HAART: highly-active antiretroviral therapy.

* For AIDS individuals only.

\section{Results}

\section{Description of the study population}

A total of 629 individuals age 20 years and over of both sexes took part in the study, being distributed in similar proportions. Mean age was of 40 years (youngest 20 years and oldest 74 years). Most of the participants (66.8\%) had AIDS, and, within this group, $94.3 \%$ used HAART. At the time of the interview $27.2 \%$ presented any of the considered co-infections, and $60.6 \%$ had had a nutritional consultation prior to the investigation. As for the nutritional status, $7.3 \%$ were undernourished and $38.6 \%$ were overweight (Table 1 ).

In terms of time with infection and time of follow-up, the study population presented 25, 50 and 75 percentile values of $1.2,4.1$, and 8.2 years for the former, and $0.7,3.3$, and 6.5 for the later.
Through the simple log-binomial model, it was seen that diagnosis $(\mathrm{p}=0.004)$ and co-infection $(\mathrm{p}<0.001)$ were associated to outcome. The variables $\operatorname{sex}(\mathrm{p}=0.594)$, age $(\mathrm{p}=0.931)$ and time of follow-up ( $p=0.320$ ) were not statistically associated (data not presented).

In the initial multiple model, the variables coinfection, diagnosis, sex, age and time of followup were included. The analysis of the $p$-value for the Wald test indicated that the first two variables should remain, in the model as significantly related to the outcome: diagnosis $(p=0.019)$ and co-infection $(\mathrm{p}<0.001)$ whereas the others would serve as controls. Thus, the final model has the same variables as the initial one. Table 2 presents prevalences, and gross and adjusted PRs with a $95 \%$ CI.

It was thus observed that the prevalence of undernourishment in AIDS individuals is 3.12 times the one seen in HIV individuals, and 3.41 times among individuals with co-infection versus individuals without co-infection (Table 2).

\section{Discussion}

This study described the anthropometric, demographic and medical characteristics of people with HIV/AIDS, age 20 years and over who are attended by the Brazilian Unified National Health System (SUS) at the City of São Paulo STD/AIDS Specialized Health Care Network.

The estimated gross prevalence of undernourishment among HIV/AIDS individuals in this study $(7.3 \%)$ is similar to the figure found by Mariz et al. 22 (8.8\% for both sexes), and higher than the one observed by Giudici et al. 16 (5.4\%), from a study carried out in the same health care network. Other Brazilian studies present prevalences ranging from $1.5 \%$ to $5.9 \%$ among men, and $3.7 \%$ to $9.8 \%$ among women $15,16,17,23$. In discordance, this study found no difference in the prevalence of undernourishment according to sex and age. The strategy of using an age group of 40 years and over was not effective to identify higher undernourishment prevalences among younger individuals with HIV/AIDS.

This study also found that the prevalences of undernourishment are higher in AIDS individuals and in individuals with at least one co-infection, versus HIV individuals and those without co-infection. As these conditions may be deleterious for the maintenance of the nutritional status in these groups, the results of this study reinforce the importance to monitor such conditions, in order to establish therapeutic plans that take into account individual needs. 
Prevalence of undernourishment and gross and adjusted prevalence ratios (PR) for undernourishment in final multiple model. HIV/AIDS individuals cared at the City Health Care Network STD/AIDS Specialized Care Clinics. City of São Paulo, Brazil, 2008-2009.

\begin{tabular}{|c|c|c|c|c|c|}
\hline \multirow[t]{2}{*}{ Co-variables } & \multirow{2}{*}{$\begin{array}{l}\text { Undernourished } \\
\qquad(n=46)\end{array}$} & \multirow{2}{*}{$\begin{array}{l}\text { Prevalence } \\
\text { Gross (\%) }\end{array}$} & \multicolumn{3}{|c|}{$\mathrm{PR}$ * } \\
\hline & & & Gross & Adjusted & $95 \% \mathrm{Cl}$ \\
\hline \multicolumn{6}{|l|}{ Diagnosis } \\
\hline $\operatorname{HIV}(n=209)$ & 6 & 2.9 & 1.00 & 1.00 & \\
\hline $\operatorname{AIDS}(n=420)$ & 40 & 9.5 & 3.56 & 3.12 & $1.23-7.93$ \\
\hline \multicolumn{6}{|l|}{ Co-infection } \\
\hline No $(n=458)$ & 21 & 4.6 & 1.00 & 1.00 & \\
\hline Yes $(n=171)$ & 25 & 14.6 & 3.56 & 3.41 & $1.81-6.44$ \\
\hline \multicolumn{6}{|l|}{ Sex } \\
\hline Males $(n=311)$ & 21 & 6.8 & 0.85 & 0.72 & \\
\hline Females $(n=318)$ & 25 & 7.9 & 1.00 & 1.00 & \\
\hline \multicolumn{6}{|l|}{ Age (years) } \\
\hline$<40(n=338)$ & 25 & 7.4 & 1.00 & 1.00 & \\
\hline $40-74(n=291)$ & 21 & 7.2 & 0.97 & 0.67 & $0.36-1.27$ \\
\hline \multicolumn{6}{|c|}{ Time of follow-up (years) } \\
\hline$<3.3(n=318)$ & 20 & 6.3 & 1.00 & 1.00 & \\
\hline$\geq 3.3(n=311)$ & 26 & 8.4 & 1.36 & 1.02 & $0.53-1.98$ \\
\hline
\end{tabular}

The literature has discussed the mechanisms that may account for what was observed, and that lead to loss of lean mass, fat, and body mass 20,32,33; a more in-depth investigation that included other variables of interest could explain the factors involved in these associations.

At the time data for this study was collected, the use of HAART was indicated for AIDS people only 34 . The current recommendation of the Brazilian Ministry of Health that this treatment should be started early on 35 may somewhat serve as a measure of undernourishment prevention. However, as the nutritional status is determined by a number of factors, this invervention, alone, does not play a pivotal role in the maintenance of the nutritional status, considering the adverse effects of HAART use, such as the increase in cholesterol levels, lipodystrophy, changes in glucose metabolism, among others 36 .

Some factors may be involved in the nutritional changes observed, such as weight loss and undernourishment, including difficulties in treatment compliance, length of treatment, and the long-term risk of adverse effects 10,11,12,37,38. Thus, one of the main contributions of this study is to call attention to situations in which the prevalence of undernourishment is higher (AIDS and co-infection), and that individuals who present such conditions require special care, with early interventions targeted towards the identified needs.

Among the limitations of this study one can mention the type of population assessed, who is cared for at public health units, and the nonconsideration, in data collection, of important information such as CD4 and viral load, and treatment-related information, such as drug regimen and length of drug use. In addition, due to lack of nutritional status indicators and classification specific for HIV/AIDS population, it was necessary to use those established for the general population. Another limiting factor is the lack of standardized referral flow to nutritional consultation, which could take place at any time during follow-up.

A difficult aspect to assess in this study is the influence of the nutritional consultation in the nutritional status. It is possible that the high proportion of people already being nutritionally monitored $(60,6 \%)$ may be reflected in a better nutritional status for the group as a whole; even though this difficulty may pose a problem, the assessment made took into account time of follow-up estimates, even if the results were not significant. On the other hand, it may be argued that despite the nutritional actions carried out, there is still much to be implemented, as $45.9 \%$ of the study population have an altered nutri- 
tional status (7.3\% undernourished, and $38.6 \%$ overweight).

Even though the use of BMI does not allow separate assessments of changes in fluid volume, lean mass or body fat, it is recommended by the WHO 26 as the method to assess the nutritional status of HIV/AIDS individuals, as it is easy to obtain.

One can even discuss the undernourishment cutoff points as a strategy of effective intervention to mitigate the condition, as, for instance, is recommended by the Guide for Nutritional Care and Support 39, to refer individuals with BMI under $20 \mathrm{~kg} / \mathrm{m}^{2}$ to nutritional care. This cutoff point, even though higher than the one established by WHO for undernourishment, would allow health professionals to complement the assessment of the nutritonal status and to make an early intervention.

Considering that one of the nutritional goals for HIV/AIDS individuals is to stabilize or regain weight, the mere weight monitoring by the health care team may be useful to prevent weight loss to impair even more their quality of life. Tang et al. 11, in a longitudinal study with 552 HIV/ AIDS individuals, concluded that weight loss is a strong predictor of mortality in the HAART era when compared to measures assessed by electrical bioimpedance.

The weight self-monitoring by adults in general for the maintenance of health is another instance of a simple measure to be encouraged, as it fosters the development of self-observation and the involvement of individuals in their broader therapeutic process 40 .
The results of this study reinforce the need for considering interventions that target undernourishment prevention and management, particularly in individuals with AIDS or co-infection.

The selection of anthropometric indicators or indexes for the clinical practice of specialized services should be reviewed and standardized, to enhance their role as a replicable, non-invasive, affordable method, able to provide early information about changes in the body composition, and an estimation of the prevalence of altered nutritional status of specific populations 41 .

It is necessary to gain a deeper understanding of the mechanisms involved in undernourishment, taking into consideration that the assessment of the nutritional status for the provision of care to HIV/AIDS individuals is one of a set of measures established by STD/AIDS specialized clinics, which also include psychological support, oral health care and others 42 .

\section{Conclusion}

Despite new medications used in HAART which substantially modify AIDS morbidity and mortality, and the recognized importance of public policies implemented in Brazil to manage the consequences of the infection 43,44 , which include a unique immunization scheme, nutritional consultation, and nutritional supplements 45 , undernourishment is still a problem, particularly in individuals with AIDS or co-infections, and it should be studied and dealt with in the scenario of care provision to HIV/AIDS individuals. 


\section{Resumen}

El estudio evaluó la prevalencia de la desnutrición en 629 personas con VIH/SIDA en 12 servicios especializados de la red municipal de salud de Sao Paulo, Brasil. Los datos se obtuvieron de los registros médicos y entrevistas durante la consulta nutricional. Se utilizó para definir la desnutrición el criterio de la Organización Mundial de la Salud (IMC $<18,5 \mathrm{~kg} / \mathrm{m}^{2}$ ). Se observó que la prevalencia de desnutrición en las personas con SIDA es 3,12 veces mayor que la observada entre las personas con VIH, y en personas con coinfección es 3,41 veces mayor que la obtenida entre las personas sin coinfección. Esto indica que estas condiciones pueden ser perjudiciales para el mantenimiento del estado nutricional, y se recomienda un estudio más profundo de los mecanismos implicados en este fenómeno, así como el desarrollo de estrategias para la atención integral en salud de las personas en situación de riesgo nutricional.

Desnutrición; Estado Nutricional; Antropometría; Sindrome de Inmunodeficiencia Adquirida; VIH

\section{Contributors}

K. C. Bassichetto took part in the design of the project, coordinated training on anthropometric measurements and data collection, took part in the analysis and was the main author of the article. D. P. Bergamaschi collaborated in the design of the project, analysis, and writing of the article. V. R. S. Garcia participated in the training, data collection, and in the writing of the article. M. A. S. M. Veras contributed with writing of the article.

\section{Acknowledgements}

To the City's STD/AIDS Program for having acquired anthropometric measuring equipment; to the School of Public Health, São Paulo University for making rooms available for the training; to Deivis E .S. Frainer for leading the training; to the health practitioners of the participating clinics for data collection: Célia M. S. Amorim, Denise S. M. Oskata, Denise V. I. Momesso, Iraci C. Bonelli, Helga F. Piloto, Janete A. Costa, Janice Chencinski, Maria Regina Nagashima, Marisia Nagamini, Nivania F Zauith, Maria Helena Vieira, and Yara L Macedo.

\section{References}

1. Polo Rodríguez R. Manual de nutrición y SIDA. 3a Ed. Madrid: Wellcome; 2002.

2. Fenton M, Silverman E. Terapia nutricional para a doença do vírus da imunodeficiência humana. In: Mahan L, Escott-Stump S, organizadores. Krause - alimentos, nutrição \& dietoterapia. 11a Ed. São Paulo: Roca; 2005. p. 980-1010.

3. Kotler DP. Nutritional alterations associated with HIV infection. J Acquir Immune Defic Syndr 2000; 25 Suppl 1:S81-7.

4. Salomon JTPD, De Truchis P, Melchior JC. Nutrition and HIV infection. Br J Nutr 2002; 87 Suppl 1:S111-9.

5. Shevitz AH, Knox TA. Nutrition in the era of highly active antiretroviral therapy. Clin Infect Dis 2001; 32:1769-75.

6. Sharpstone D, Murray C, Ross H, Phelan M, Craner R, Lepri AC, et al. The influence of nutritional and metabolic status on progression from asymptomatic HIV infection to AIDS-defining diagnosis. AIDS 1999; 13:1221-6.
7. Heath KV, Hogg RS, Singer J, Chan KJ O'Shaughnessy MV, Montaner JSG. Antiretroviral treatment patterns and incident HIV-associated morphologic and lipid abnormalities in a population-based cohort. J Acquir Immune Defic Syndr 2002; 30:440-7.

8. Knox TA, Zafonte-Sanders M, Fields-Gardner C, Moen K, Johansen D, Paton N. Assessment of nutritional status, body composition, and human immunodeficiency virus-associated morphologic changes. Clin Infect Dis 2003; 36 Suppl 2:S63-8.

9. Almeida L, Jaime P. Aspectos atuais sobre nutrição e Aids na era da terapia antirretroviral de alta atividade. J Bras Aids 2006; 7:4-8.

10. Polsky B, Kotler D, Steinhart C. HIV-associated wasting in the HAART era: guidelines for assessment, diagnosis, and treatment. AIDS Patient Care STDS 2001; 15:411-23. 
11. Tang AM, Forrester J, Spielman D, Knox TA, Tchetgen E, Gorbach SL. Weight loss and survival in HIV-positive patients in era of highly active antiretroviral therapy. J Acquir Immune Defic Syndr 2002; 31:230-6.

12. Kotler DP. Challenges to diagnosis of HIV-associated wasting. J Acquir Immune Defic Syndr 2004; 37 Suppl 5:S280-3.

13. Anjos EM, Pfrimer IK, Machado AA, Cunha SFC, Salomão RG, Monteiro JP. Nutritional and metabolic status of HIV-positive patients with lipodystrophy during one year of follow-up. Clinics 2011; 66:407-10.

14. Leite LHM, Sampaio ABMM. Risco cardiovascular: marcadores antropométricos, clínicos e dietéticos em indivíduos infectados pelo vírus HIV. Rev Nutr PUCCAMP 2011; 24:79-88.

15. Oliveira OMV, Medeiros RS, Nascimento MAB, De Boni MS. Perfil nutricional e fatores de risco para obesidade central de pessoas que vivem com HIV/ AIDS. Com Ciênc Saúde 2008; 19:305-14.

16. Giudici KV, Duran ACFL, Jaime PC. Self-reported body changes and associated factors in persons living with HIV. J Health Popul Nutr 2010; 28:560-6.

17. Jaime PC, Florindo AA, Latorre MRDO, Brasil BG, Santos ECM, Segurado AAC. Prevalência de sobrepeso e obesidade abdominal em indivíduos portadores de HIV/AIDS, em uso de terapia antirretroviral de alta potência. Rev Bras Epidemiol 2004; 7:65-72.

18. Florindo AA, Latorre MRDO, Santos ECM, Borelli A, Rocha AS, Segurado AAC. Validação de métodos de estimativa da gordura corporal em portadores do HIV/AIDS. Rev Saúde Pública 2004; 38:643-9.

19. Jaime PC, Florindo AA, Latorre MRDO, Segurado AAC. Central obesity and dietary intake in HIV/ AIDS patients. Rev Saúde Pública 2006; 40:634-40.

20. Albuquerque MDM, Ximenes RAA, Maruza M, Batista JDL, Albuquerque MFPMA. Índice de massa corporal em pacientes coinfectados pela tuberculose-HIV em hospital de referência da cidade de Recife, Estado de Pernambuco, Brasil. Epidemiol Serv Saúde 2009; 18:153-60.

21. Curti MLR, Almeida LB, Jaime PC. Evolução de parâmetros antropométricos em portadores do vírus da imunodeficiência humana ou com síndrome da imunodeficiência adquirida: um estudo prospectivo. Rev Nutr PUCCAMP 2010; 23:57-64.

22. Mariz CA, Albuquerque MFPM, Ximenes RAA, Melo HRL, Bandeira F, Oliveira TGB, et al. Body mass index in individuals with HIV infection and factors associated with thinness and overweight/obesity. Cad Saúde Pública 2011; 27:1997-2008.

23. Kroll AF, Sprinz E, Leal SC, Labrêa MG, Setúbal S. Prevalence of obesity and cardiovascular risk in patients with HIV/AIDS in Porto Alegre, Brazil. Arq Bras Endocrinol Metab 2012; 56:137-41.

24. Programa Nacional de DST/AIDS, Secretaria de Vigilância em Saúde, Ministério da Saúde. Manual clínico de alimentação e nutrição na assistência a adultos infectados pelo HIV. Brasília: Ministério da Saúde; 2006.

25. Lohman T, Roche AF, Martorell R. Anthropometric standardization reference manual. Champaign: Human Kinetics Books; 1988.
26. World Health Organization. Physical status: the use and interpretation of anthropometry. Report of a WHO Expert Committee. Geneva: World Health Organization; 1995. (WHO Technical Report Series, 854).

27. Rickbaugh TM, Jamieson BD. A challenge for the future: aging and HIV infection. Immunol Res 2010; 48:59-71.

28. Meir-Shafir K, Pollack S. Accelerated aging in HIV patients. Rambam Maimonides Med J 2012; 3:e0025.

29. Smith RL, de Boer R, Brul S, Budovskaya Y, van der Spek H. Premature and accelerated aging: HIV or HAART? Front Genet 2013; 3:328.

30. Somarriba G, Neri D, Schaefer N. The effect of aging, nutrition, and exercise during HIV infection. HIV AIDS (Auckl) 2010; 2:191-201.

31. Reichenheim ME, Coutinho ESF. Measures and models for causal inference in cross-sectional studies: arguments for the appropriateness of the prevalence odds ratio and related regression. BMC Med Res Methodol 2010; 10:66.

32. Kotler DP. Human immunodeficiency virus-related wasting: malabsorption syndromes. Semin Oncol 1998; 25(2 Suppl 6):70-5.

33. Mulligan K, Tai VW, Schambelan M. Energy expenditure in human immunodeficiency virus infection. N Engl J Med 1997; 336:70-1.

34. Programa Nacional de DST/AIDS, Secretaria de Vigilância em Saúde, Ministério da Saúde. Recomendações para terapia antirretroviral em adultos e adolescentes infectados pelo HIV: 2005/2006. 6a Ed. Brasília: Ministério da Saúde; 2007. (Série Manuais, 2).

35. Departamento de DST, Aids e Hepatites Virais, Secretaria de Vigilância em Saúde, Ministério da Saúde. Protocolo clínico e diretrizes terapêuticas para adultos vivendo com HIV/Aids. Brasília: Ministério da Saúde; 2013.

36. Silva EFR, Lewi DS, Vedovato GM, Garcia VRS, Bassichetto KC. Nutritional and clinical status, and dietary patterns of people living with HIV/AIDS in ambulatory care in São Paulo, Brazil. Rev Bras Epidemiol 2010; 13:677-88.

37. Macallan DC, Noble C, Baldwin C, Jebb SA, Prentice AM, Coward WA, et al. Resting expenditure and wasting in human immunodeficiency virus infection. N Engl J Med 1995; 333:83-8.

38. Wanke CA, Silva M, Knox TA, Forrester J, Speigelman D, Gorbach SL. Weight loss and wasting remain common complications in individuals infected with human immunodeficiency virus in the era of highly active antiretroviral therapy. Clin Infect Dis 2000; 31:803-5.

39. Food and Nutrition Technical Assistance Project. HIV/AIDS: a guide for nutrition, care and support. Washington DC: Academy for Educational Development; 2001.

40. Gomes DL, Ferreira EAP, Souza CMC. Automonitoramento e adesão a dois tipos de regras nutricionais em adultos com diabetes tipo 2. Acta Compartamentalia 2012; 20:327-42.

41. WHO Working Group. Use and interpretation of anthropometric indicators of nutritional status. Bull World Health Organ 1986; 64:929-41. 
42. Segurado AC, Miranda SD, Latorre MRDO; The Brazilian Enhancing Care Initiative Team. Evaluation of the care of women living with HIV/AIDS in São Paulo, Brazil. AIDS Patient Care STDS 2003; 17:85-93.

43. Barreto ML, Teixeira MG, Bastos FI, Ximenes RA Barata RB, Rodrigues LC. Successes and failures in the control of infectious diseases in Brazil: social and environmental context, policies, interventions, and research needs. Lancet 2011; 377: 1877-89.
44. Dourado I, Veras MASM, Barreira D, Brito AM. Tendências da epidemia de AIDS no Brasil após a terapia antirretroviral. Rev Saúde Pública 2006; 40 Suppl:9-17.

45. Barbosa RMR, Fornés NS. Avaliação nutricional em pacientes infectados pelo Vírus da Imunodeficiência Adquirida. Rev Nutr PUCCAMP 2003; 16:461-70.

Submitted on $06 /$ Oct $/ 2013$

Final version resubmitted on 09/Jul/2014

Approved on 16/Jul/2014 